\title{
PENERAPAN METODE PROJECT WORK DALAM PEMBELAJARAN PRAKTIK UNTUK MENINGKATKAN KOMPETENSI PRAKTIK BODY OTOMOTIF PADA MAHASISWA PENDIDIKAN TEKNIK MESIN FKIP UNS TA 2012/2013
}

\author{
Basori \\ Prodi. Pend. Teknik Informatika dan Komputer, Jurusan Pendidikan Teknik dan Kejuruan, FKIP, UNS \\ Kampus UNS Pabelan Jl. Ahmad Yani 200, Surakarta, Telp/Fax 0271718419
}

\begin{abstract}
This reseach aims to study how to improve the student competence by implementation of project work learning method. Specifically this research aims to study the percentage of mastery learning on automotive body practice lecture.

This research used PTK ( Classroom Action Research) and was performed two cycles. The research was conducted in the Mechanical Engineering Department at PTK UNS PTK with 7th semester students. And the student took a course automotive body practice. The number of the student was 34 person. Data was collected by a test or tests of competence. Analysis of the data used descriptive qualitative analysis

The results shows that student competence's increase in automotive body practice learning. From two cycles, there has been an increase in from 72.85 to be 77.24 . In the second cycle to 70.01 . While the percentage of students who have not passed are also increasing. From $11.8 \%$ to $2.9 \%$. In the second cycle of $0 \%$.
\end{abstract}

Keywords: competence, automotive body practice, project work

\section{PENDAHULUAN}

Pendidikan di era global saat ini telah mengalami kemajuan yang sangat pesat. Hal ini dapat dilihat dari perubahan paradigma baru di dunia pendidikan. Di mulai dari pembelajaran tradisional menuju konstruktivisme, adanya perubahan pembelajaran berpusat pada guru ke pembelajaran berpusat pada siswa, dan masih banyak yang lainnya.

Sejalan dengan kemajuan tersebut di atas, perlu adanya peningkatan dan pengembangan dalam mutu layanan pendidikan di institusi pendidikan. Sementara itu pendidikan di Indonesia masih banyak yang menganut pandangan bahwa pengetahuan sebagai perangkat fakta-fakta yang harus dihafal. Pembelajaran di kelas masih berfokus kepada guru/dosen sebagai sumber pengetahuan, kemudian metode ceramah menjadi satu-satunya metode pembelajaran yang diterapkan. Oleh karenanya diperlukan sebuah strategi dan metode belajar baru yang lebih memberdayakan siswa/mahasiswa, yakni sebuah metode belajar yang mendorong siswa/mahasiswa untuk lebih, aktif, kreatif, dan dinamis dalam menemukan, menyusun dan mengkomunikasikan hasil belajarnya. Dengan model pembelajaran ini siswa/mahasiswa akan berada pada proses penerapan antara konsep dan realitas yang ada, sehingga siswa/mahasiswa dengan mudah dapat mengingat konsep yang diperoleh untuk kemudian diterapkan.
Salah satu metode yang dapat dilaksanakakan adalah project work. Dengan pembelajaran project work, pebelajar menjadi terdorong lebih aktif di dalam belajar mereka, instruktur berposisi di belakang dan pebelajar berinisiatif, instruktur memberi kemudahan dan mengevaluasi proyek baik kebermaknaannya maupun penerapannya untuk kehidupan mereka sehari-hari. Produk yang dibuat pebelajar selama proyek memberikan hasil yang secara otentik dapat diukur oleh guru atau instruktur di dalam pembelajarannya. Oleh karena itu, di dalam Project Work, guru atau instruktur tidak lebih aktif dan melatih secara langsung, akan tetapi instruktur menjadi pendamping, fasilitator, dan memahami pikiran pebelajar. Proyek pebelajar dapat disiapkan dalam kolaborasi dengan instruktur tunggal atau instruktur ganda, sedangkan pebelajar belajar di dalam kelompok kolaboratif antara 4-5 orang. Ketika pebelajar bekerja di dalam tim, mereka menemukan keterampilan merencanakan, mengorganisasi, negosiasi, dan membuat konsensus tentang isuisu tugas yang akan dikerjakan, siapa yang bertanggungjawab untuk setiap tugas, dan bagaimana informasi akan dikumpulkan dan disajikan. Keterampilan-keterampilan yang telah diidentifikasi oleh pebelajar ini merupakan keterampilan yang amat penting untuk keberhasilan hidupnya, dan sebagai tenaga kerja merupakan keterampilan yang amat penting di tempat kerja. 
Program Studi Pendidikan Teknik Mesin Jurusan Pendidikan Teknik dan Kejuruan FKIP UNS Surakarta merupakan salah satu LPTK bidang teknik terutama teknik mesin dan teknik otomotif. Animo masyarakat untuk menempuh pendidikan di Program Studi Pendidikan Teknik Mesin JPTK FKIP UNS Surakarta setiap tahun mengalami peningkatan dilihat dari jumlah peminat dibanding daya tampungnya. Kondisi mahasiswa Program Studi Pendidikan Teknik Mesin JPTK FKIP UNS Surakarta untuk setiap angkatan mahasiswa apabila dilihat dari asal sekolah diperoleh data 10-15\% dari SMK, 5\% dari MA dan 80\% dari SMA. Kondisi tersebut secara tidak langsung merupakan hambatan bagi dosen pada awal masa perkuliahan untuk melakukan transfer of knowledge/skill terutama matakuliah yang bersifat praktik dimana ketrampilan motorik sangat dikedepankan. Permasalahan tersebut muncul karena jumlah dosen pengampu matakuliah praktik belum mencukupi dibanding jumlah mahasiswa yang menempuh matakuliah praktik. Hal tersebut tentu akan berdampak pada rendahnya tingkat keterserapan materi yang disampaikan oleh dosen dan berakibat prestasi mahasiswa menjadi turun. Pada semester gasal TA 2012/2013 matakuliah praktik meliputi menggambar mesin, praktik body otomotif, praktik pemesinan lanjut, praktik karya inovatif, teknik merancang dan CAD I.

\section{LANDASAN TEORI}

\section{Pembelajaran Berbasis Proyek (Project Based Learning)/ Project Work}

Pembelajaran berbasis proyek (projectbased learning) adalah sebuah model atau pendekatan pembelajaran yang inovatif, yang menekankan belajar kontekstual melalui kegiatan-kegiatan yang kompleks (CORD, 2001; Thomas, Mergendoller, \& Michaelson, 1999; Moss, Van-Duzer, Carol, 1998). Fokus pembelajaran terletak pada konsep-konsep dan prinsip-prinsip inti dari suatu disiplin studi, melibatkan pebelajar dalam investigasi pemecahan masalah dan kegiatan tugas-tugas bermakna yang lain, memberi kesempatan pebelajar bekerja secara otonom mengkonstruk pengetahuan mereka sendiri, dan mencapai puncaknya menghasilkan produk nyata (Thomas, 2000).

Fokus pembelajaran terletak pada konsep-konsep dan prinsip-prinsip inti dari suatu disiplin studi, melibatkan pebelajar dalam investigasi pemecahan masalah dan kegiatan JIPTEK, Vol. VI No.1, Januari 2013 tugas-tugas bermakna yang lain, memberi kesempatan pebelajar bekerja secara otonom mengkonstruk pengetahuan mereka sendiri, dan mencapai puncaknya menghasilkan produk nyata (Thomas, 2000). Biasanya memerlukan beberapa tahapan dan beberapa durasi tidak sekedar merupakan rangkaian pertemuan kelas serta belajar kelompok kolaboratif. Proyek memfokuskan pada pengembangan produk atau unjuk kerja (performance), yang secara umum pebelajar melakukan kegiatan: mengorganisasi kegiatan belajar kelompok mereka, melakukan pengkajian atau penelitian, memecahkan masalah, dan mensintesis informasi.

\section{a. Keuntungan Project Work}

Pendekatan Project Work mempunyai keuntungan yang lebih baik dibandingkan dengan metode-metode yang lain. Jennifer Railsback (2002: 9) menyebutkan beberapa keuntungan dari Project Work, yaitu :

"(1) preparing children for the workplace, (2) increasing motivation, (3) connecting school with reality, (4) providing collaborative opportunities to construct knowledge, (5) increasing social and communication skills, (6) increasing problem solving skills, (7) enabling students to make and to see connection between disciplines, (8) providing opportunities to contributes to their school or community, (9) increasing self esteem, (10) allowing children to use their individual learning strenghts and diverse approaches to learning, (11) providing a practical, real world way to learn to use technology."

Sementara Moursund, Bielefeldt, \& Underwood (1997) meneliti sejumlah artikel tentang proyek di kelas yang dapat dipertimbangkan sebagai bahan testimonial terhadap guru, terutama bagaimana guru menggunakan proyek dan persepsi mereka tentang bagaimana keberhasilannya.

\section{b. Pelaksanaan Project Work}

Rudolf Tippet dan Antonio Amoros (2003: 13) menyebutkan ada enam fase atau tahap pelaksanaan project work, yaitu :

1. Informing (Menginnformasikan)

2. Planning (Merencanakan)

3. Deciding (Memutuskan)

4. Implementing (Mengimplementasikan)

5. Controlling (Mengendalikan) 


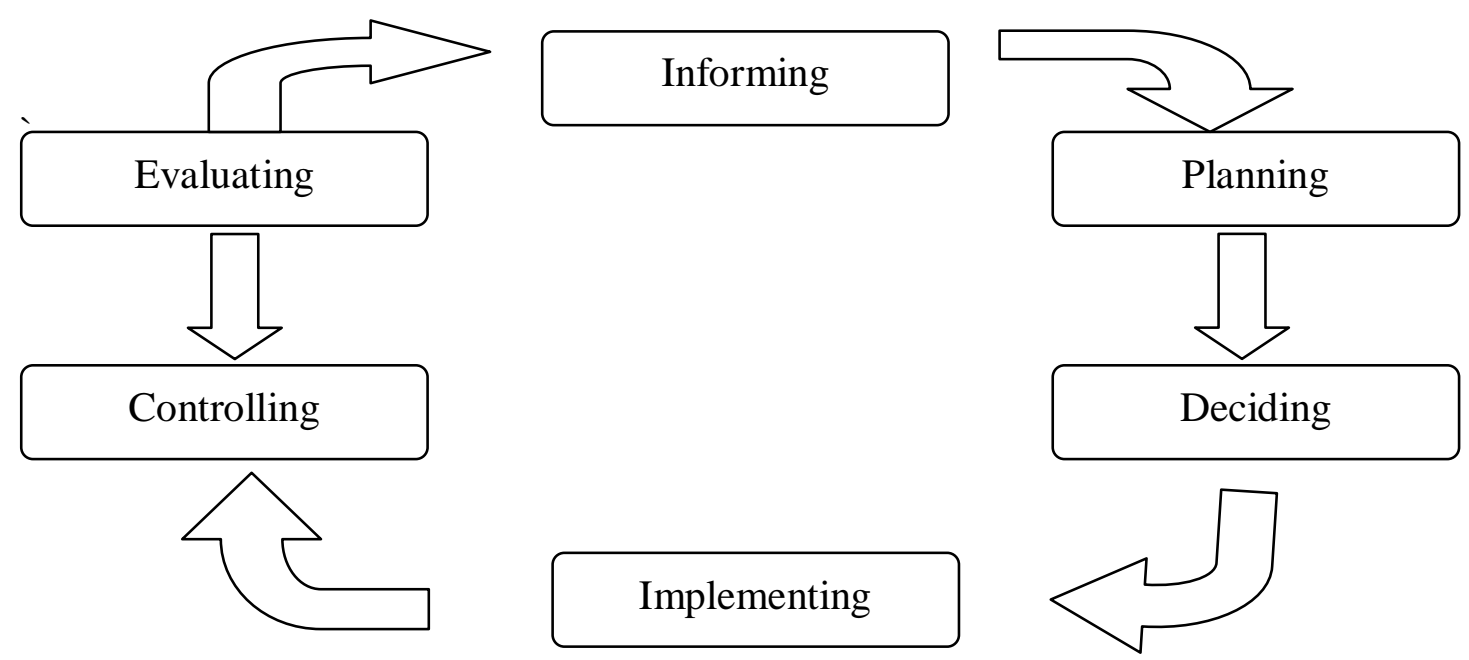

Gambar. 1 Fase Pelaksanaan Project Work

1. Informing (Menginformasikan)

a. Mengumpulkan informasi yang diperlukan

b. Mendefinisikan tugas proyek (project tasks)

c. Meyakinkan bahwa peserta didik familier dengan pekerjaan proyek

d. Mendorong peserta didik bekerja secara kolaboratif

2. Planning (Merencanakan)

a. Mengeset rencana kerja

b. Mengorganisasikan pekerjaan

c. Sosialisasi integrasi pekerjaan di antara peserat didik

3. Deciding (Memutuskan)

a. Membuat keputusan secara kolektif

b. Belajar mengevaluasi permasalahan

c. Menumbuhkan komunikasi di antara peserta didik.

4. Implementing (Mengimplementasikan)

a. Aktifitas berbasis pada pengalaman

b. Proses pengecekan pekerjaan dengan rencana

c. Pekerjaan dikerjaan secara independent oleh peserta didik

5. Controlling (Mengendalikan)

a. Proses mengevaluasi diri terhadap pekerjaan

6. Evaluating (Mengevaluasi)

a. Diskusi secara bersama-sama di dalam kelompok, setelah proyek selesai.

b. Sistem yang fleksibel dan criteria secara terbuka. c. Aturan pembimbing

d. Partisipasi penuh dari kelompok kerja.

\section{Kompetensi Praktik Body Otomotif}

Kata kompetensi berasal dari kata "competence", oleh Echols dan Shadiliy (2000:132) diterjemahkan sebagai kecakapan , kemampuan dan kompetensi, sedang beberapa ahli lain seperti Gonezi (1992:225) mengatakan:

Competence is to describe a person as competent in area of work if they have the knowlegde, skills, and attitudes to be able to function at some minimum acceptable level. To more precise, competence is something that canbe attributed to an individual on the basis of inferences drawn from performance in assessment or actual work.

Dari pengertian kompetensi di atas, maka Gonezi mengatakan bahwa kompetensi tersebut merupakan suatu atribut dari seseorang yang tampak melalui perbuatannya atau kinerjanya berdasarkan hasil penilaian atau pekerjaannya.

Pusat Kurikulum Balitbang Depdiknas (2002) memberikan pengertian bahwa kompetensi merupakan perpaduan dari pengetahuan, ketrampilan, dan nilai-nilai dasar yang direfleksikan dalam kebiasaan berfikir dan bertindak kompeten bagi peserta didik secara konsisten dan terus-menerus sampai menjadi kompeten, dalam arti memiliki pengetahuan, ketrampilan, nilai-nilai dasar untuk melakukan pekerjaan tertentu.

Praktik body otomotif merupakan salah satu mata kuliah keahlian otomotif yang 
dipelajari di Prodi PTM FKIP UNS . Kompetensi praktik body otomotif terdiri dari: (1) Pembacaan dan pemahaman gambar teknik; (2) Kontribusi komunikasi di tempat kerja; (3) Mengikuti Prosedur Keselamatan, Kesehatan Kerja;dan Lingkungan; (4) Penggunaan dan Pemeliharaan Peralatan danPerlengkapan Tempat Kerja;(5) Penggunaan dan Pemeliharaan Alat Ukur; (6) Pelaksanaan pemeriksaan keamanan/kelayakan kendaraan; (7) Melaksanakan prosedur pengelasan, pematrian,pemotongan dengan panas dan pemanasan; (8) Melaksanakan pekerjaan sebelum perbaikan; (9) Melepas, menyimpan dan mengganti/memasang panel-panel bodi kendaraan, bagian-bagian panel dan perangkat tambahannya;

Mempersiapkan permukaan untuk pengecatan ulang; (11) Melepas dan mengganti/mengepas pelindung moulding, transfer/gambar-gambar hiasan, stiker dan decal/lis, spoiler; (12) Melepas dan mengganti rangkaian/listrik/unit elektronik; (13) Mempersiapkan bahan dan peralatan pengecatan; (14) Melaksanakan prosedur masking; (15) Memasang perapat komponen kendaraan ; (16) Mempersiapkan komponen kendaraan untuk perbaikan pengecatan kecil; (17) Mempersiapkan dan mengecat komponenkomponen plastik; (18) Pelaksanaan pengkilatan dan pemolesan; (19) Memilih dan menggunakan hiasan/trim berperekat; (20) Membuat (fabrikasi) komponen fiberglas/bahan komposit; (21) Memperbaiki komponen fiberglas/bahan komposit; (22) Memperbaiki komponen bodi menggunakan dempul timah (lead wiping); (23) Melaksanakan pemasangan anti karat dan peredam suara; (24) Membersihkan permukaan kaca; (25)Melakukan pembersihan setempat permukaan luar/dalam.

\section{METODE PENELITIAN}

Penelitian ini dilaksanakan di Program Studi Pendidikan Teknik Mesin PTK FKIP UNS, mahasiswa semester 8 yang mengambil mata kuliah Praktik Body Otomotif. Mata kuliah ini merupakan salah satu mata kuliah konsentrasi mesin otomotif, sehingga tidak semua mahasiswa semester 8 mengambil mata kuliah ini. Jumlah mahasiswa yang mengambil mata kuliah ini pada TA 2012/2013 ada 34 mahasiswa.

Penelitian ini berlangsung selama 3 bulan, dimulai pada pertengahan bulan september 2012 dan berakhir pada pertengahan bulan nopember 2012.

Penelitian ini merupakan pengembangan model yang dilanjutkan dengan kajian tindakan kelas melalui beberapa siklus, dengan model konstelasi berikut:

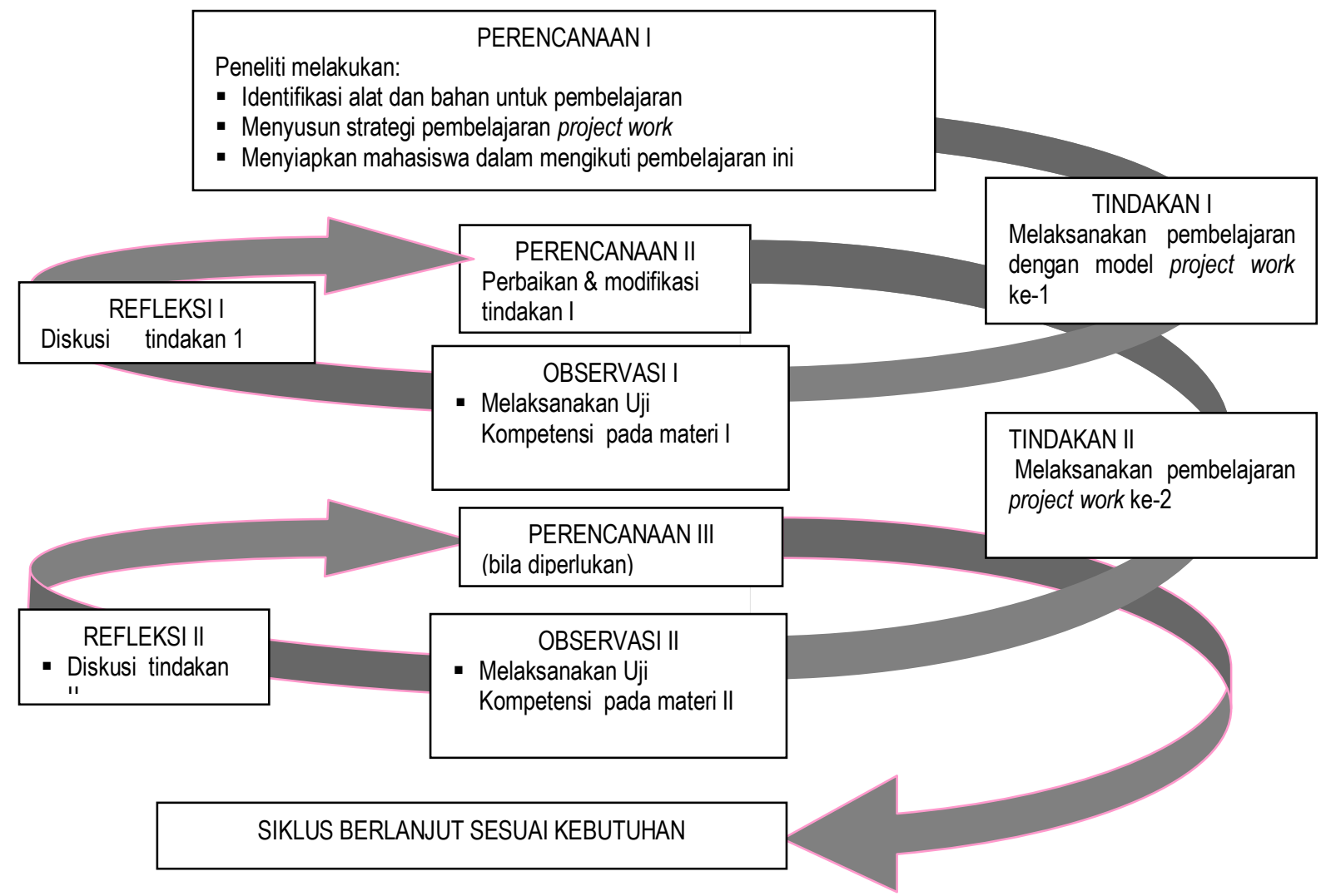

Gambar 2. PTK dengan model Stephen Kemmis 


\section{HASIL DAN PEMBAHASAN}

1. Siklus I

a. Perencanaan

Persiapan tindakan 1 yang dilakukan pada penelitian ini adalah:

1 Menetapkan subyek penelitian

2 Menetapkan materi pelajaran

3 Menetapkan metode/strategi pembelajaran project work.

4 Menyusun rencana pelajaran

5 Menetapkan waktu pembelajaran

6 Menyiapkan bahan / alat test.

7 Melakukan pre-test sebelum tindakan dilaksanakan.

\section{b. Tindakan}

Penelitian ini dilakukan dengan mnegikuti langkah-langkah pembelajaran dengan metode project work. Tahap pelaksanaan project work pada tindakan 1, yaitu :

1. Informing (Menginnformasikan) Dosen memberikan topik pada mata kuliah Praktik Body Otomotif yang menjadi dasar dalam pelaksanaan project ini. Topik diambil dari kompetensi yang harus dikuasai mahasiswa dalam MK Praktik Body Otomotif. Pengambilan topik berdasarkan pembagian komponen mobil, dimana nantinya dalam pelaksanaan project akan terdistribusi beberapa kompetensi yang harus dikuasai dalam komponen tersebut. Pada tindakan 1 ini, komponen yang digunakan adalah perbaikan kap mesin.

2. Planning (Merencanakan)

Mahasiswa diharuskan membuat rencana awal pengerjaan kap mesin dengan rinci dalam bentuk proposal kerja. Hasil proposal dikonsultasikan dengan dosen.

3. Deciding (Memutuskan)

Kelompok mahasiswa membuat alur pekerjaan perbaikan kap mesin, kemudian mendiskusikan penanggung jawab dari setiap tahap pekerjaan. Di samping itu, mahasiswa juga diwajibkan membuat estimasi dana pengeluaran biaya perbaikan kap mesin ini.

4. Implementing

(Mengimplementasikan)

Mahasiswa bersama kelompoknya mengerjakan project sesuai dengan kapabilitas masing-masing. Pekerjaan ini membutuhkan waktu yang cukup lama.

Berikut ini dokumentasi kegiatan implementasinya di dalam praktik.

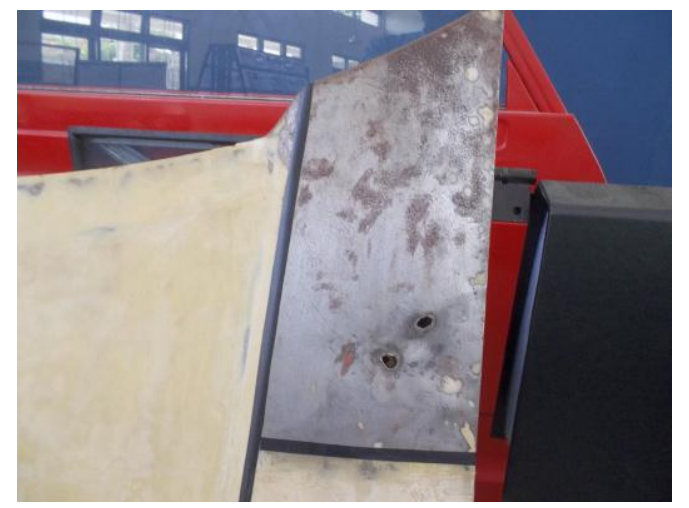

a. Kondisi awal

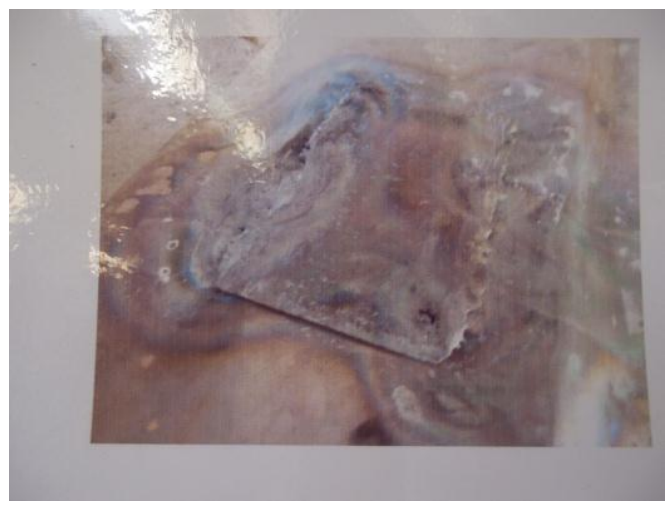

b. Proses Pengelasan 


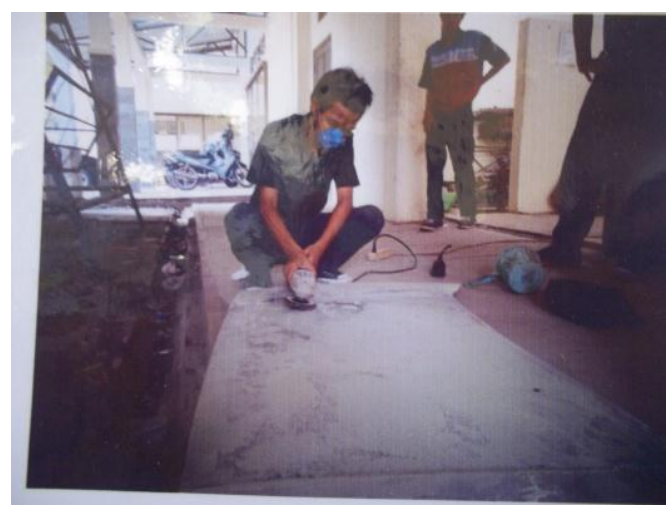

c. Proses Pendempulan

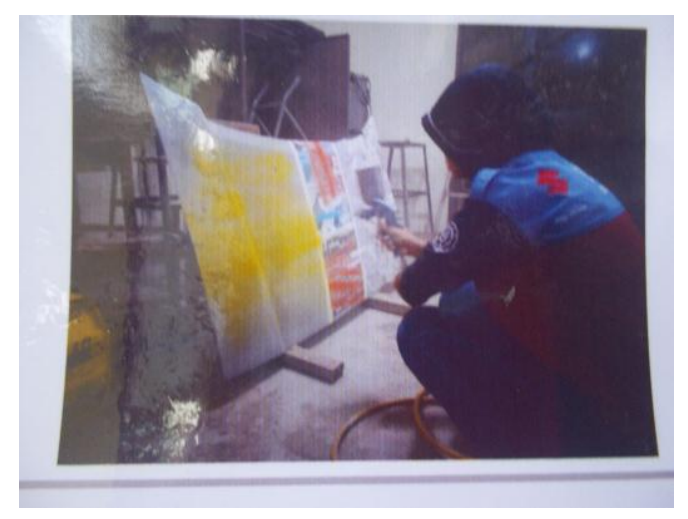

e. Proses pengecatan

5. Controlling (Mengendalikan)

Dalam pelaksanaan project perbaikan kap mesin ini, mahasiswa dengan dosen melakukan quality control terhadap hasil setiap tahap perbaikan

6. Evaluating (Mengevaluasi)

Hasil project berupa kap mesin yang sudah di finishing, kemudian diteliti kembali. Dalam pengecekan ulang ini dimaksudkan untuk mendapatkan kepastian hasil akhir yang sempurna dan memperbaiki

\section{c. Pengamatan}

Selama kegiatan pembelajaran praktik, peneliti melakukan pemantauan terhadap proses pembelajaran dan terhadap hasil

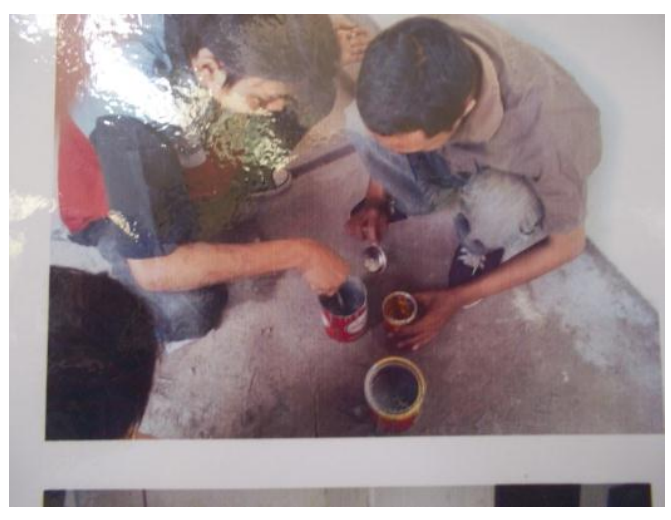

d. Pencampuran cat

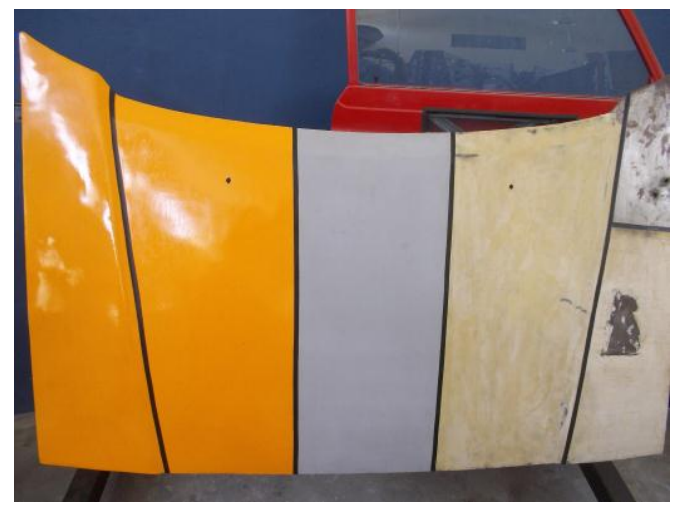

f. hasil akhir

belajar mahasiswa untuk setiap siklusnya.

Pemantauan terhadap proses pembelajaran dilakukan dengan menggunakan alat bantu catatan. Hasil pemantauan tersebut digunakan untuk menentukan jenis tindakan perbaikan pada kegiatan belajar mengajar siklus berikutnya.

Pemantauan terhadap hasil belajar siswa dilakukan pada setiap akhir siklus dengan memberikan uji kompetensi (UK) untuk mengukur kemampuan mahasiswa terhadap kompetensi mata kuliah ini.

Berikut ini adalah nilai pre-test sebelum tindakan dilakukan dengan nilai uji kompetensi setelah tindakan 1 dilakukan pada mahasiswa. 
Tabel 1. Perbedaan Nilai Kondisi Awal (pre-test) dan UK Tindakan I

\begin{tabular}{|ll|c|c|}
\hline \multicolumn{1}{|c|}{ Pencapaian } & Kondisi Awal & Tindakan I \\
\hline 1. & Nilai terendah & 55 & 58 \\
2. & Nilai tertinggi & 83 & 87 \\
3. & Rata-rata kelas & 72,85 & 77,24 \\
4. $\begin{array}{l}\text { Banyak mahasiswa belum mencapai } \\
\text { batas kompeten (Nilai <60) }\end{array}$ & 4 & 1 \\
5. & Persentase mahasiswa belum kompeten & $11,8 \%$ & $2,9 \%$ \\
6. $\begin{array}{l}\text { Banyak siswa telah mencapai dan } \\
\text { melampaui batas kompeten (Nilai } \geq 60)\end{array}$ & 30 & 33 \\
\hline
\end{tabular}

\section{d. Refleksi}

Setelah melalui tahap pengamatan/observasi, pelaksanaan pembelajaran praktik dengan menggunakan metode project work ini dievaluasi. Pelaksanaan project work yang mengadopsi dari Rudolf Tippet dan Antonio Amoros, cukup menghasilkan peningkatan terhadap hasil uji kompetensi mahasiswa. Langkahlangkah project work diawali dengan menginformasikan kepada mahasiswa tentang project yang akan dilaksanakan. Untuk melangkah ke topiknya, doen memberikan pengayaan berupa pemberian materi secara ceramah dan diskusi. Pada tahap ini, mahasiswa cukup antusias dengan pengayaannya, terlihat dari peran aktif mahasiswa dalam proses pengayaan tersebut. Langkah kedua dan ketiga, mahasiswa diberikan tugas untuk merencanakan dan memutuskan pemecahan masalah terhadap topik yang diberikan. Pada siklus 1 ini, topik yang diberikan adalah perbaikan kap mesin. Rencana dan putusan masalah dibuat dalam bentuk proposal kerja yang nantinya akan dievaluasi. Banyak hal yang diperoleh dari proposal kerja mahasiswa ini, salah satunya adalah pemecahan masalah terhadap kap mesin yang rusak, memcantumkan beberapa kompetensi yang ada dalam mata kuliah praktik body otomotif ini, seperti pengelasan, pendempulan, pengecatan, dan polishing. Dengan menerapkan proposal kerja ini, langkah kerja mahasiswa dapat lebih terkoordinasi dan terukur. Langkah ketiga, mengimplementasikan program yang ada dalam proposal kerja ke dalam pelaksanaan project secara nyata. Pada tahap ini, mahasiswa dibagi menjadi 3 kelompok. Masing-masing kelompok terdiri dari 11 mahasiswa. Dalam pelaksanaan project, mahasiswa dibagi ke dalam pekerjaan berdasarkan kompetensi yang ada dalam pekerjaan perbaikan kap mesin ini. Langkah ini membutuhkan waktu yang relatif agak lama, dan penguasaan kompetensi mahasiswa hanya terpusat dari apa yang menjadi tanggung jawab semula. Langkah keempat, pengendalian dan evaluasi hasil kerja. Pada tahap ini tidak ada permasalahan, karena dimaksudkan untuk memperbaiki hasil kerja yang telah dibuat.

\section{Siklus II}

\section{a. Perencanaan}

Perencanaan untuk tindakan kedua yang dilakukan adalah sebagai berikut:

1 Menetapkan materi pelajaran

2 Menerapkan metode project work yang telah dimodifikasi

3 Menyusun rencana pelajaran

4 Menetapkan waktu pembelajaran

5 Menyiapkan bahan / alat test.

\section{b. Tindakan}

Pada tindakan 2 ini terdapat modifikasi dari metode project work yang telah dilaksanakan di siklus 1 . Terdapat perbaikan di tahap implementing, dimana pada siklus 1, mahasiswa bekerja berdasarkan pembagian tugas dan kapabilitasnya masing-masing. Untuk di siklus 2 ini, tahap implementing, mahasiswa dibuat urutan kerja dan rotasi kerja. Dengan cara ini, diharapkan mahasiswa dapat menguasai semua kompetensi yang ada dalam pekerjaan ini, hanya saja membutuhkan waktu yang lebih lama dari siklus 1. Sedangkan komponen yang menjadi media pembelajaran adalah perbaikan pintu samping mobil. 
Berikut ini adalah dokumentasi hasil kegiatan project work pada tindakan

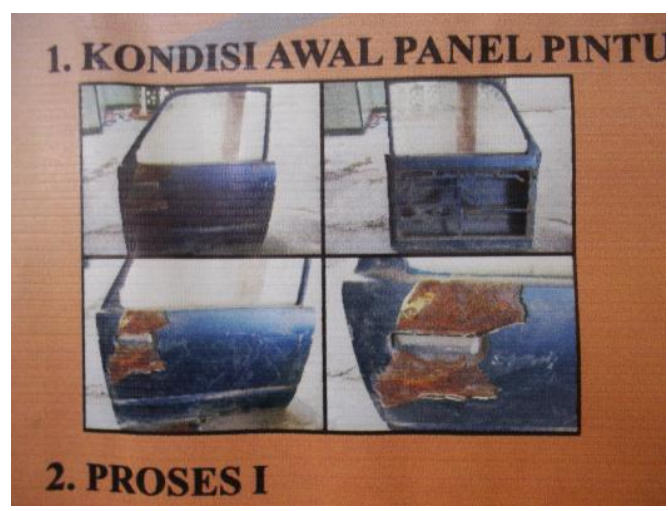

a. Kondisi awal

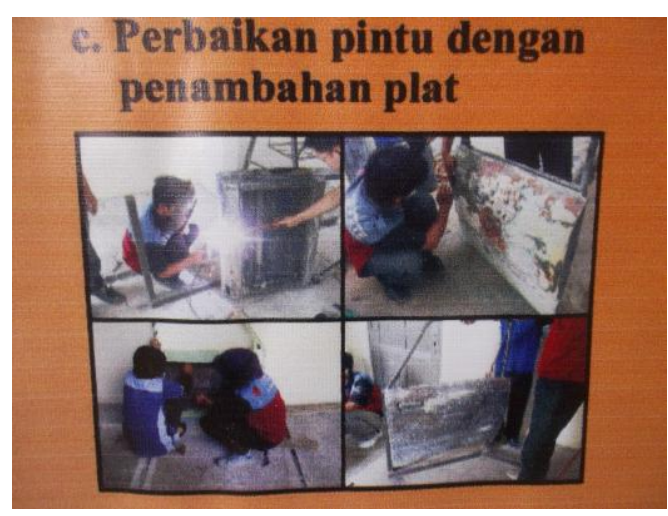

c. Penambahan plat dengan las

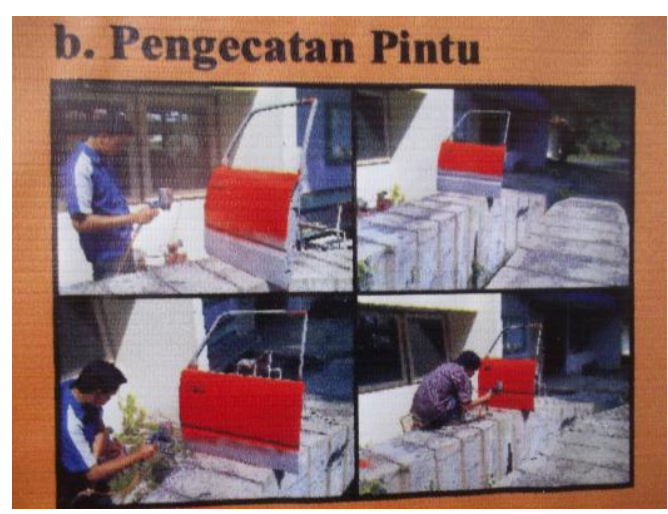

e. Proses pengecatan

\section{c. Pengamatan}

Pemantauan terhadap hasil belajar maha siswa/kompetensi mahasiswa dilakukan pada akhir siklus dengan memberikan uji kompetensi. kedua.

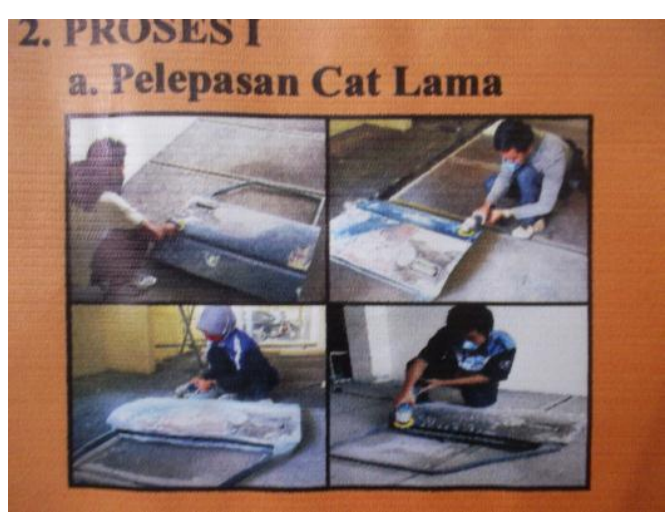

b. Proses pelepasan cat lama

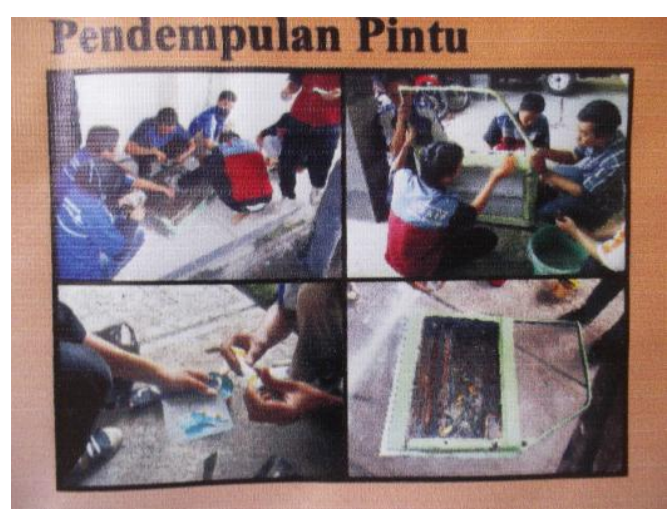

d. Proses pendempulan

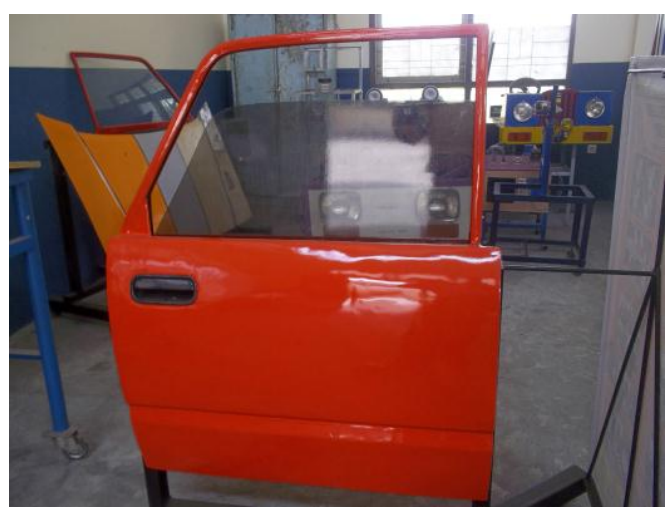

f. Hasil akhir

Berikut ini adalah nilai perbandingan antara nilai UK setelah tindakan I dilakukan dengan nilai UK setelah tindakan II dilakukan pada mahasiswa. 
Tabel 2. Perbedaan Nilai UK Tindakan I dan UK Tindakan II

\begin{tabular}{|c|c|c|}
\hline Pencapaian & Tindakan I & Tindakan II \\
\hline 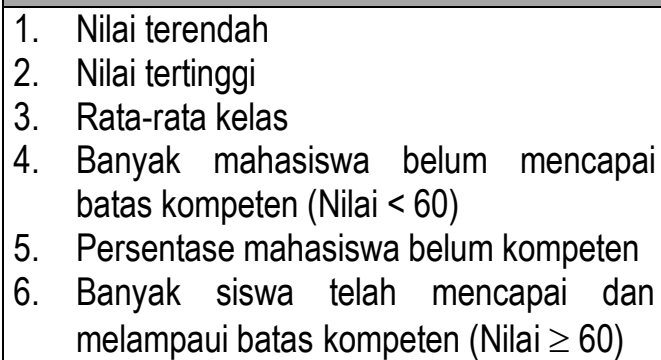 & $\begin{array}{c}58 \\
87 \\
77,24 \\
1 \\
2,9 \% \\
\\
33\end{array}$ & $\begin{array}{c}70 \\
92 \\
79,01 \\
0 \\
0.00 \% \\
\\
34\end{array}$ \\
\hline
\end{tabular}

\section{d. Refleksi}

Pada siklus kedua ini, hasil observasi terhadap pelaksanaan project work cukup baik, terlihat dari peningkatan nilai uji kompetensi yang dilakukan di akhir siklus. Pada siklus kedua ini, terdapat perbaikan pada tahap implementasi project work, dimana pada siklus pertama, mahasiswa cenderung fokus yang menjadi tanggung jawabnya, sehingga penguasaan kompetensi secara keseluruhan tidak dapat terpenuhi. Dengan modifikasi di tahap ini, yaitu mengadakan urutan kerja dan rotasi kerja, penguasaan kompetensi mahasiswa lebih optimal.

Penelitian Tindakan Kelas (PTK) yang telah dilaksanakan ini memberikan penguatan terhadap pentingnya metode project work di pendidikan vokasi dalam pembelajaran praktik. Di sini terlihat adanya peningkatan rata-rata kelas dari uji kompetensi yang dilakukan dengan standar kompeten 60. Sebelum tindakan reratanya 72,85 menjadi 77,24 pada tindakan pertama dan 79,01 pada tindakan kedua.

Dilihat dari persentase ketuntasan kompetensi mahasiswa, juga terjadi peningkatan dari sebelum tindakan, persentase yang belum tuntas $11,8 \%$ menjadi $2,9 \%$ pada tindakan pertama dan $0 \%$ pada tindakan kedua.

\section{SIMPULAN DAN SARAN}

Berdasarkan hasil penelitian dan pembahasan di atas dapat disimpulkan bahwa terjadi peningkatan kompetensi mahasiswa. Dari dua kali siklus, terlihat adanya peningkatan rerata kelas dari sebelum tindakan yaitu 72,85 menjadi 77,24. Pada siklus kedua menjadi 70,01. Sedangkan persentase mahasiswa yang belum lulus juga terjadi peningkatan. Dari 11,8\% menjadi 2,9\%. Pada siklus kedua $0 \%$.

Berdasarkan simpulan di atas peneliti mengajukan saran sebagai berikut:
1. Dalam proses pembelajaran, dosen harus selalu mengembangkan metode penyampaian materinya agar ketercapaian ketuntasan belajar tercapai.

2. Pengelola pendidikan vokasi menyediakan infrastruktur yang dibutuhkan dalam pelaksanaan sistem pembelajaran agar berjalan lancar.

\section{DAFTAR PUSTAKA}

Anas Sudijono. (2005). Pengantar Evaluasi Pendidikan. Jakarta: Raja Grafindo Persada

Buedewick, I. (2003). Aspect of Methodology and Education Psychology in ProjectOriented Studies. Makalah disajikan dalam International Workshop on Project Oriented Learning di Hanzehogeschool Groningen, Fakulty of Technology

Depdiknas (2007) Petunjuk Teknis Penyelenggaraan Uji Kompetensi Keahlian Sekolah Menengah Kejuruan. Jakarta

Farida Yusuf Tayipnapis. (1989). Evaluasi Program. Jakarta: Proyek Pengembangan LPTK.Dirjen Dikti. Depdikbud.

Fernandes, HJX. (1984).Evaluation of Educational Programs. Jakarta: National Education Planning Evaluation ang Curriculum Development

Mergendoller, J.R., \& Thomas, J.W. (2000). Managing Project Based Learning: Principles from the Field. Novato, CA: Buck Institute for Education.

Michael M Grant; Robert Maribe Branch. (2005). Project-Based Learning In a Middle School: Tracing Abilities Through The Artifact Learning [versi elektronik]. Journal of Research on Technology in Education, 38,1, 65-98

Moti Frank \& Abigail Barzilai.(2006). ProjectBased Technology: Instructional Strategy 
for Developing Technological Literacy [versi elektronik]. Journal of Technology Education, Vol. 18 No. 1,39-53.

Railsback, J. (2002). Project Based Instruction: Creating Excitement for Learning. Portland, Oregon: Northwest Regional Educational Laboratory

Richard, N. Savage, Chen, K \& Vanasupa, L. (2007). Integrating Project-based Learning throughout the Undergraduate Engineering Curriculum [versi elektronik]. Journal of STEM Education, Vol 8, 15-27

Stufflebeam, DL, \& Shinkfield, AJ. (1985). Systematic

Massachusetts:Kluwer-Nijhoff Publishing

Suharsimi Arikunto \& Cepi Safrudin AJ. (2004). Evaluasi Program Pendidika,Panduan Teoritis Praktis bagi Praktisi Pendidikan. Jakarta:BPT Bumi Aksara

Suharsimi Arikunto. (1988). Penilaian program pendidikan. Jakarta:PT Bina Aksara

Thomas, J.W. (2000). A Review od Research on Project-Based Learning. California: The Autodesk Foundation. Available on: http://www.autodesk.com/foundation.

Tippet, R \& Amoros, A. (2003). The Project Method in Vocational Training. Mannheim: InWent

Waras Kamdi. (2001). Section 1-Pengantar. Pembelajaran Berbasis Proyek: Model Potensial untuk Peningkatan Mutu Pembelajaran. Diambil tanggal 16 September $2008 \quad$ dari http://waraskamdi.com/content/view/55/1 $\underline{6 /}$

Waras Kamdi. (2001). Section 2-Mengapa Pembelajaran Berbasis Proyek. Pembelajaran Berbasis Proyek: Model Potensial untuk Peningkatan Mutu Pembelajaran. Diambil tanggal 16 September 2008 dari http://waraskamdi.com/content/view/54/1 $\underline{6 /}$

Waras Kamdi. (2001). Section 3-Dukungan Teoritik Pembelajaran Berbasis Proyek. Pembelajaran Berbasis Proyek: Model Potensial untuk Peningkatan Mutu Pembelajaran. Diambil tanggal 16 September $2008 \quad$ dari http://waraskamdi.com/content/view/52/1 6/

Waras Kamdi. (2001). Section 3-Konsep dan Karakteristik Belajar Berbasis Proyek.
Pembelajaran Berbasis Proyek: Model Potensial untuk Peningkatan Mutu Pembelajaran. Diambil tanggal 16 September 2008 dari http://waraskamdi.com/content/view/53/1 $\underline{61}$

Waras Kamdi. (2001). Section 4-Keuntungan Belajar Berbasis Proyek. Pembelajaran Berbasis Proyek: Model Potensial untuk Peningkatan Mutu Pembelajaran. Diambil tanggal 16 September 2008 dari http://waraskamdi.com/content/view/51/1 6/

Weiss, CH. (1972).Evaluation research methods for assessing program effectiveness.Englewood Cliffs:Prentice Hall,Inc.

Worthern, BR \& Sanders, JR. (1973) Educational Evaluation: theory and practice.Belmont,California. Wadsworth Publishing Company 